\title{
SHAYKH MUHAMMAD ARSYAD AL-BANJARI'S THOUGHT ON EDUCATION
}

\author{
Husnul Yaqin \\ IAIN Antasari, Banjarmasin - Indonesia
}

\begin{abstract}
Shaykh Muhammad Arsyad Al-Banjari is a religious central figure who has key roles in introducing new religious ideas in South Kalimantan. In this context, his thoughts are not only in the area of religion but also in education. There are at least four significant points of AlBanjari's thought on education. First, the educational paradigm was under the umbrella of neo-Sufism which emphasized on bayani, irfani and burbani. Second, the institutional education introduced is a semi-formal education in which the study was concentrated in one place. Third, the teaching methods used are macro and micro. Macro method includes contextualization, centralization and integralization. Micro method covers uswah hasanah, halaqah, lecturing, and question and answer. Above all, the material for religius study in Al-Banjari's period was deeper and wider compared to the era before Shakh his arrival. The use of various books for studying was so illustrative.
\end{abstract}

Keywords: Islamic education, paradigm, institution, method and material.

\section{Introduction}

Azyumardi Azra stated that the $18^{\text {th }}$ century is one of the most dynamic eras in religious-intellectual history of Islam. The source of this dynamic was the religious leaders' network centralized in Mecca and Madinah. Those who were involved in this network came from various countries with different scholarly tradition and brought them to Haramayn. This network was considered creating new scientific discourse that, in turn, took part in developing new ideas. The most 
striking idea from this religious intellectualism was the harmonization between shari'ah and Sufism approach (Neo-sufism/sufistic fiqh). ${ }^{1}$

Reconciliation and harmonization between shari'ah and Sufism had long been emphasized by Islamic leaders such as al-Ghazāli and alQushayri; however, this reconciliation reached the peak through the religious leaders' network. Leaders in this network believed that an extravagant, tendentious and excessive Sufism could be controlled by total commitment to shari ${ }^{\prime} a h$. This new commitment to shari'ah and Sufism encouraged serious efforts toward Islamic society's socio-moral construction. $^{2}$

Azra noted that a number of students of Haramayn Islamic leaders (shaykh) who came from Nusantara (Indonesia) had significant roles in spreading new ideas. In fact, those students were the core of the driven Islamic-intellectual tradition at that time. ${ }^{3}$ One of those students was Shaykh Muhammad Arsyad al-Banjarit from South Kalimantan.

Al-Banjari was known as the brightest student among his Indonesian's colleagues. Shagir Abdullah called him as Matahari Islam Nusantara (the sun of Indonesian Islam) ${ }^{5}$ and Syaifuddin Zuhri (former Minister of Religious Affairs, 1962-1967) called him as "Mercusuar Islam Kalimantan" (The light house of Kalimantan Islam). ${ }^{6}$ Azra placed him as an Islamic scholar who not only had significant roles in religious leaders' network but is also as the first Islamic scholar who built Islamic institutions and introduced new ideas in Kalimantan, ${ }^{7}$ and to be more specific in South Kalimantan.

\section{The Life of Shaykh Muhammad Arsyad al-Banjari}

Al-Banjari was born on Thursday 17 March 1710/15 Safar 1122 H, in Lok Gabang, Martapura, South Kalimantan. His given name is

\footnotetext{
1 Azyumardi Azra, Jaringan Ulama (Bandung: Mizan, 1994), p. 16.

2 Ibid., p. 18.

3 Ibid., p. 251.

${ }^{4}$ Syekh Muhammad Arsyad al-Banjari is respectively abbreviated as Arsyad.

${ }^{5}$ HW. Shagir Abdullah, Syekh Muhammad Arsyad al-Banjari, Matahari Islam (Pontianak: Yayasan Pendidikan \& Dakwah al-Fatanah, 1983), p. 12.

${ }^{6}$ Saifuddin Zuhri, Sejarah Kebangkitan Islam dan Perkembangannya di Indonesia (Bandung: PT. al-Ma'arif, 1981), p. 176.

${ }^{7}$ Azra, Jaringan Ulama, p. 251.
} 
Ja'far. ${ }^{8}$ Al-Banjari's full name is Arsyad bin Abdullah bin Abubakar bin Abdul Rasyid (Aka. Abdul Haris). It is even argued that al-Banjari's genealogical line reaches the Prophet Muhammad. ${ }^{9}$ He passed away on 13 October 1710/6 Shawwāl 1227 in Dalam Pagar Village, and was burried in Kalampayan, Martapura. ${ }^{10}$

Al-Banjari was a prominent religious leader from Banjarmasin, South Kalimantan. However, historically, al-Banjari's grandfather was from Mindanao, southern part of the Phillipines. He had royal blood from Islamic Kingdom of Kebutantalan Sulu. ${ }^{11}$ Al-Banjari's parents,

8 Abu Daudi, "Riwayat Hidup Syekh Muhammad Arsyad al-Banjari," International Seminar paper Pemikiran Syekh Muhammad Arsyad al-Banjari (Banjarmasin, 2003), p. 3.

9 This is traceable as follows: Arsyad bin Abdullah bin Abubakar bin Abdurrasyid bin Abdullah al-Idrus al-Magribi bin Abubakar al-Hindi bin Ahmad bin Husin bin Abdullah bin Syaikh bin Abdullah al-Idrus bin Abu Bakar as-Sakrani bin Abdurrahman as-Saqafi bin Muhammad Mawla ad-Duwaylah bin Ali bin Alwi bin al-Faqih alMuqaddam Muhammad bin Ali bin Muhammad bin Ali Khala' Qasim bin Alwi bin Muhammad bin Alwi bin Abdullah bin Ahmad al-Muhajir Ilallah bin Isa an-Naqib bin Muhammad an-Naqib bin Ali al-'Arid bin Ja'far as-Sadiq bin Muhammad al-Baqir bin Ali Zainal Abidin bin Sayyidina Husin bin 'Ali bin Abi Talib, Sayyidatina Fatimah azZahra binti Muhammad. See, Anonim, Silsilah Tuan Guru Haji Zaini Gani (Surabaya: n.p., n.d.), p. 1.

${ }^{10}$ Abdullah, Syekh Muhammad Arsyad, p. 6.

${ }^{11}$ It is said that around the year of 1650 s, the history of Banjar recorded a fleet consisted of dozens of ships, intended to go on the pilgrimage to Mecca. The ships belonged to the Sultan of Sulu kingdom of Mindanao, the Philippines. They were carrying two important passenger; Abdurrasyid and Muharam. These two people were aboard in different ships. The ship for these two people were large and luxurious. Other ships served as the guards to maintain the safety of the sons of the king, in which one of them was the future king, to perform the pilgrimage. After the ships reached the Straits of Makassar (Celebes Sea), they were attacked by a great hurricane. All the guardian ships wrecked and sunk. Only two ships were survived from the hurricane and they were in heavily damaged and broken. These were the ships of Muharam and Abdurrasyid. Muharam's ship stranded at the Estuary of the Mahakam River (East Kalimantan),and Abdur Rashid's stranded at estuary of the Barito River (Banjarmasin, South Kalimantan). Apparently, Muharam, who was stranded in Mahakam river, was somewhat lucky because later he was married with Aji Maemuna, the sister of Sultan Kutai, Idris. While Abdurrasyid who was aground in Barito river, was not that lucky. He lived in Banjarmasin as a commoner to hide his identity as the heir of sultanate of Sulu. At that time, the Sultan of Banjar Kingdom was Sultan Tahlilullah (1660-1663). Sultan happened not to be so nice to the people who came from the Philippines who at that time known as the pirates who often rob merchant's ships, including merchant ships from Banjar. Another version said that Abdurrasyid deliberately fled and left the kingdom of Sulu to Banjar kingdom in search of peace and safety. It was because the kingdom of Sulu had fallen into the hands of Spanish 
Abdullah and Aminah, were a simple family, kind hearted and very respected by the society including the nobles and the members of kingdom. They were very obedient and devoted to God. Sultan Banjar also loved them very much. Every time sultan visited his citizen in villages, he always spared some times to stop by at al-Banjari parents' house. It was because Banjarese people including sultan always honored the descendent of prophet Muhammad p.u.h. Besides, Abdullah's uncles; Muqsin, Yusuf, and Rangga Kusuma gave lot of contributions to the kingdom especially in religious matters.

There were no formal schools either Islamic boarding school (pondok pesantren) or Islamic school in Banjar during al-Banjari's childhood. Therefore, it was predicted that informally, al-Banjary got his first Islamic education within his family household. ${ }^{12}$ After having

conqueror after a bloody battle with the natives that at that time the majority was Muslims, under the leadership of Sultan Sulaiman. It's important to notice that Islam in the Philippines first appeared in the Sulu region and then Sulu Islamic kingdom was built and ruled by Muslims. Mindanao's name came later after Sulu. Mindanao itself is the name given by the Muslims. The words min indina meant our group, a group of the Prophet Muhammad because. the first person who spread Islam in Sulu was descendants of the Prophet Muhammad. However, the Spaniards called the people of Islam in Sulu, Mindanao, as the Moro people. See M. Luthfi Sidik, Salasilah Siti Fathimah, Sebutir Telur (Salatiga: n.p., 1992), pp. 1-3.

12 Arsyad lived in a household who loved religion. The situation affected his behavior and his religious sensibilities. It was obvious that he got his first informal education from his parents who were very devoted to religion.Since he was in the womb till he was child, his parents always took good care of him physically and mentally with love and tenderness. Arsyad's early education was always in a positive direction to places of worship, group of religious study and other facilities that foster the spreading of Islam. He was also accustomed to hearing, reciting, memorizing and writing good names of God, word of Allah and Tayyibah sentences, practicing it, and of course, was trained to perform prayer, fasting, praying and other acts of worship. See Abu Daudi, Maulana Syekh Muhammad Arsyad al-Banjari (Martapura: Sullam al-Ulum, 1996), p. 19. 
informal education at home, he studied in the kingdom ${ }^{13}$ and continued to Haramayn. ${ }^{14}$

In Haramayn (Mecca and Madinah), al-Banjari learnt from Shaykh Ataillah bin Ahmad al-Misri, Shaykh Muhammad bin Sulaiman alKurdi, Shaykh Muhammad bin Abd al-Karim Samman al-Madani, Shaykh Ahmad bin Abdul Mun'im ad-Damanhuri, Shaykh Ibrahim arRa'is az-Zamzami, Shaykh Abi al-Fadil Muhammad Murtada, Shaykh Hasan bin Ahmad Akisy al-Yamani, Shaykh Salim bin Abdullah alBasri, Shaykh Siddiq bin Umar Khan, Shaykh Abdullah bin Hijazi asSyarqawi, Shaykh Abdurrahman bin Abdul Aziz al-Magribi, Shaykh Abdurrahman bin Sulaiman al-Ahdal, Shaykh Abdurrahman bin Abdul Mubin al-Fatani, Shaykh Abdul Gani bin Shaykh Muhammad Hilal, Shaykh Abid as-Sandi, Shaykh Abdul Wahab at-Tantawi, Shaykh Abdullah Mirgani, Shaykh Muhammad bin Ahmad al-Jauhari and Shaykh Muhammad Zein bin Faqih Jalaluddin Aceh. ${ }^{15}$

\footnotetext{
13 One day, Sultan Khamidullah (sultan Kuning 1700 to 1734), checked the situation of his society. He met Arsyad who was 8 years old and was interested in Arsyad's intelligence, memory, especially his ability to draw of the beauty of nature in its natural state. Sultan, then, asked Arsyad's parents to let him adopt Arsyad so that he can be educated and improved his talents. In the palace, Arsyad got lessons and other religious sciences, in a relatively short time, Arsyad could finish the Qur'an. See Ahmad Basuni, Jiwa yang Besar Syekh Muhammad Arsyad al-Banjari (Bandung: Pustaka Galunggung, 1971), p. 8. Also see Daudi, Maulana Syekh Mubammad Arsyad, p. 26.
}

14 When Arsyad was about 30 years old, in 1740 AD, at the expense of the sultanate, Arsyad headed Haramayn on a trading ship. The Possible routes of Arsyad were from the port Kuin Banjarmasin, leading to the port of Batavia Sunda Kelapa, then to Aceh, Indonesia's last port (the Veranda of Mecca), where he waited for a ship to India. In India, he then looked for a ship that could take him to the Hadramaut, Yemen, or directly to Jeddah, Mecca. This trip took almost half a year one way, or even more. Arsyad lived in Haramayn for about 30 years. It was about 25 years in Mecca and 5 years in Medina. While in Mecca, he bought a house at the expense of the sultanate of Banjar, in the village of Syamiyah and the house was named Barhat Banjar. The house is still there and well maintained until now by the sheikh from Banjarmasin and usually in Haj season, it is always visited by group of Haj from South Kalimantan. Martin van Bruinessen, Kitab Kuning (Bandung: Mizan, 1995), p. 48. See also M.S. Kadir, "Syekh Muhammad Arsyad al-Banjari Pelopor Dakwah Islam di Kalimantan Selatan," Mimbar Ulama No. 6 (1976), pp. 69-79.

15 Daudi, Maulana Sheikh Muhammad Arsyad, pp. 25-26. Arsyad had many teachers. Among them, there are four most important teachers that became his idol and gave lots of influence to Arsyad's thought namely Sheikh Ataillah bin Ahmad al-Misri, Shaykh Muhammad ibn Sulayman al-Kurdi, Shaykh Muhammad bin Abdul Karim Samman al-Madani and Shaykh Ahmad bin Abdul Mun'im ad-Damanhuri. These four 
Because of high intelligence, himmah, faith, obedience to God, after studying from various teachers for 30 years in Haramayn, al-Banjari succeeded to master 35 field of studies including Islamic teaching and non-Islamic science, diniyah and 'asriyah study ${ }^{16}$, jawāhir (exoteric) and bawatin (esoteric) study. Among those sciences, he was the best at fiqh and tasawwuf. ${ }^{17}$

men, at that time, were very famous particularly in Haramayn and around the Middle East and Islamic world in general. First, Ataillah, a scholar from Egypt, completed his education at al-Azhar University. He mastered the various Islamic sciences and he was known as a muhaddis (hadith expert) and is considered a leading scholar who was excellent in the study of hadith isnad. He later moved to Mecca and was given a title by al-Kattani as Nazil Haramain. He was very active in teaching at the two holy lands mainly in the circle of study at Masjid al-Haram. He was one of prominent sheikh and many people demanded him for teaching. He was a good friend of Sheikh Muhammad bin Abdul Karim Samman and he authored several books, including al-Hijaz Nihayah fi al-haqiqah al-Majaz. Next is Shaykh Muhammad ibn Sulayman al-Kurdi. He (17151780 AD) was a great scholar who had also mastered various branches of Islamic knowledge, but he was very famous as a prominent fiqh expert from the Kurds. He's one of Sheikh Muhammad bin Abdul Karim Samman's teachers of in the study of the Shari'a. He was once a mufti called Shafi Imam Haramayn (a religious leader in the two holy lands), and wrote several important books of figh. One of Indonesia's most famous book (and still in print today) is his book entitled al-Madaniyyah Hawasyi, a commentary (hasyiyyah) on the work of Ba-Fadl, al-al-Hadramiyah Muqadimah-or to be exact a further comment on Sharh previously written by Ibn Hajar, al-Minhaj Qawim. Furthermore, Sheikh Muhammad bin Abdul Karim al-Samman Madani (17181775 AD) was a great scholar and one of wali Qutub. He was even called as Sultanul Awliya (the king of all carers), the expert of tarikat, hakikat and ma'rifat who was born in Medina from the family of Quraysh. He was the founder of tarikat Sammaniyah that blended into one tarikat Khalwatiyah, Naqsyabandiyah, Qadiriyah, Syaziliyah and Adiliyyah. He also, served as the gatekeeper of the Prophet Muhammad's tomb. In Medina, he stayed at the historic home owned by Abubakar ra, and taught at Madrasah Sanjariyyah which was visited by many students from distant lands. He authored several books of Sufism. Among others are Proceedings of the al-Ilahiyyah Nafahat Kayfiyyah Suluk fi al--tariqah Muhammadiyyah. Finally, Sheikh Ahmad bin Abd al-Mun'im Damanhuri (1690-1778 AD) from Cairo. He was the great scholars who mastered the various branches of Islamic knowledge especially knowledgeof kalam (theology) and mantiq (logic). He occupied a position as Shaykh al-Azhar (1768-1778 AD) and often traveled to the Haramayn to teach many students there. Azyumardi Azra, Scholars Network (Bandung: Mizan, 1994), p. 138 and p. 249. See also van Bruinessen, kitab kuning, p.19.

${ }^{16}$ Daudi, Maulana Syekh Mubammad Arsyad, p. 27.

17 Karel A. Steenbrink, Beberapa Aspek. Tentang Islam di Indonesia Abad ke-19 (Jakarta: Bulan Bintang, 1984), p. 91. 
Having finished his study abroad, al-Banjari began his activities such as doing comparison study, ${ }^{18}$ dissolving his daughter's marriage, ${ }^{19}$ preparing future Islamic scholars ('ulamā') ${ }^{20}$, spreading and developing

18 Before arriving in his hometown, he had traveled to several areas. The first, he stopped in Riau on the invitation of his close friend, Abdussamad to participate in spreading Islam there and became a teacher at Indra Sakti Kingdom, Penyengat, Island. Second, Arsyad stopped in Batavia (now Jakarta) for several months. He met group of Islamic scholars headed by Sheikh Abdul Qahar. On that occasion, he expressed his views on the role of scholars as mandate holders of the Prophets. The scholars have an obligation to guide people to the right path to get happiness in the world and happiness in the hereafter. During his stay in Betawi, Arsyad took time to visit a mosque for Friday prayers. While having meeting/ silaturrahmi with Betawi people, he also had the opportunity to re-examine the direction of qibla of mosque that he visited. Apparently there were several mosques that the qibla were not quite right; among other was Jembatan Lima mosque, which deviate several degrees from the correct direction of Qibla. Up to now, in the mihrāb of Jembatan Lima the mosque's mibräb is found Arabic written which states that the mosque Qiblah direction was corrected to the right by 25 degrees by Sheikh Muhammad Al-Banjari Arsyad on 4 Safar 1186 M (About May 7, 1772 AD). Other mosques' qibla which were also corrected by Arsyad were Luar Batang mosque and Pekojan mosque. In connection with the rectification of this Qibla direction, Hamka mentioned that Arsyad has conducted research on the manufacture of all mosques in Java, and he admitted that the mosque which its mibräb faced the correct direction of Qiblah was Demak mosque. Third, Arsyad ever stopped and paid a visit to Sambas, West Kalimantan together Daud alFatani, to meet Islamic scholars there and to look at the situation also the spreading of Islamic education there. See Shagir Abdullah, Sheikh Muhammad Arsyad al-Banjari, Author Sabil al-Mubtadin (Kuala Lumpur: Khazanah Fataniyah, 1990), pp. 32-46. Hamka, History of Muslims IV (Jakarta: Bulan Bintang, 1976), p. 149

${ }_{19}$ While He was still in Haramayn, Arsyad married his daughther, Syarifah with his best friend, Abdul Wahab on the basis of wali mujbir. At the same time, In Banjar, the kingdom has married Arsyad's daughter with a man named Usman on the basis of wali bakim, and she got a son named Muhammad As'ad. Both marriages took place at the same day, date, and month but few hours different. The marriage in Makkah preceded the marriage in Martapura for few hours. Thus, Arsyad decided that the marriage in Makkah was sovereign, while marriage in Martapura falled by itself. It meant that the bond of marriage between Syarifah and Usman was dissolved (cancelled), on the other hand, the bond of marriage between Abdul Wahab and Syarifah was confirmed. Daudi, Maulana Sheikh Mubammad Arsyad, pp. 38-39.

${ }^{20}$ Upon his return from studying in Haramayn, Arsyad did not live in the palace again. Arsyad asked for land to the Sultan for the residence and place for education to teach the prospective Islamic scholars as well as development centers. This place eventually became a village named Kampung Dalam Pagar. Zafri Zamzam gave the village the terms such as candradimuka crater for prospective Islamic scholars. See Zafri Zamzam, Shaykh Mubammad al-Banjari Arsyad: Interpreting the Great Ulema Propagation (Banjarmasin: Works, 1979), p. 10. 
Islam among the Banjarese people ${ }^{21}$, keeping the society's Islamic belief, visiting friends, forming shariyah, 22 opening farms and having many descendents.

21 Although Arsyad had a special place to study with many students, he still did religious preach into the midst of society, both in cities and villages, and in royal families and in ordinary ones.. According to Hafiz Ansyari, there are four direct positive impact made Arsyad religious preach for the development of Islam in the Kingdom of Banjar: (a) the community felt honored by great leader they admired, so they were inspired to deepen the knowledge of religion and obedience to apply the teaching, (b) the creation of a harmonious relationship between the Isamic scholars with society, let alone such figure as Arsyad, in addition to a great scholar, he was sultan's beloved son. For the community, such status has its own charismatic values, (c) Arsyad could find out the religious life of the community, so that he could develop further training programs, and (d) his preach encouraged the progress of religious study that he founded.. A. Hafiz Ansary HZ, "The Role of Sheikh Muhammad alBanjari Arsyad in the development of Islam in South Kalimantan," Khazanah, Vol. I, No.1 (February 2002), pp. 19-20.

${ }^{22}$ In Banjar kingdom, there was an officer (penghulu) who was in charge of religious matters. Even though there was no clear explanation about this position, it was predicted not far different of those in Java because the kingdom of Banjar was strongly influenced by Javanese kingdoms, especially in the political culture. According G.F. Pijper, the officer (penghulu) was in charge of completing matters related to religious matters based on Islamic law. Penghulu can be called qadi in Arabic, although a penghulu had less skills compared to a qadi. Penghulu also served as Head of the Religious court. If the position of penghulu in Banjar is the sama as in Java, it can be assumed that Banjar also had a court. At the time, Arsyad upgraded this institution to Syar'iyyah Court headed by a mufti. The establishment of these institutions was done by Sultan based on the advice from Arsyad. The institution aimed to keep religious laws or regulations in the kingdom of Banjar in accordance with Islamic law. According to Karel A. Steenbrink, a Mufti is similar to Chairman of the Supreme Court today, which controlled and served held as an agency for an appeal of the ordinary court. Indeed, in this structure, the mufti was the Chairman of Supreme Court (Chief of Syar'iyyah court), and under that position was qadi who served as the executor of the law and manage the rule so that Islamic law can be applied naturally. Commenting on the formation of this Syar'iyyah Court, Karel A.Steenbrink stated that the Religious courts and perhaps, General Courts were also re-arranged by Arsyad and because of his effort, a mufti was appointed.. The first mufti appointed by the Sultan Shaykh As'ad was Muhammad bin Usman who was Arsyad's grandchild, while the first qadi was Abu Su'ud, Arsyad's child with bidur. This institution, is not only functioned to silence the various disputes happened in society, but also more importantly to strengthen the implementation of Islamic law in the kingdom of Banjar, especially at this period the executors were the people who were truly religious and under Arsyad's guidance. As a follow-up of the existence of this institution, upon the recommendation of Arsyad, the sultan also enforced Islamic criminal law in the territory of Banjar kingdom. The penal code included the death penalty for apostates of Islam, the last punishment for adultery, fought by Sultan and his fellow for those who did not perform prayers and so 
Even though al-Banjari had lots of activities, he still had chance to do self reelection and continue studying and did some writings. His publication can be categorized in two forms; kitäb (book) and risälah (treatise). Book contains some chapters which are divided into articles. Meanwhile, Treatise is an academic paper discussed one issue that is broken down into some articles. Al-Banjari had around 21 writings; on Tawhịid (Risālat Usūul al-Dīn, Risālat Tuhfat al-Räghibin, Risālat al-Qawl alMukibtasar, Risālab fī Bayān al-Qad̄à wa al-Qadr wa al-Wabā', Risālat Majmū'), on Fiqh (Parukunan Basar, Risälat Luqtah al-Ajlān, Kitāb alNikēạ, Kitāb Faràid, Risālat Fatwā Shaykh Atàillāh, Risālat Fatwā Shaykh Sulaymān Kurdi, Risālat 'Ilm Falak, Kitāb Hashiyah Fath al-Jawàd, Risālat Bulügh al-Marä, Risālat Tubfat al-Aḅbāb, Kitāb Sabīl al-Mubtadīn), on Tasawnuf (Risālat Fatḥ al-Rabmān, Risālat Kanz al-Ma'rifah, Kitab Barencong), on educational science (Risālat Bidāyah al-Mubtadi' wa 'Umdah

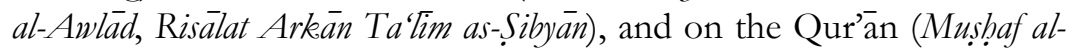
Qur'an al-Karim). ${ }^{23}$

\section{Shaykh Muhammad Arsyad al-Banjari's thought on Education}

\section{Islamic Education Paradigm}

According to Azyumardi Azra, al-Banjari, as an exponent who played significant roles in spreading new ideas was the core of intellectual tradition in that era. His new innovated ideas were not necessarily brand new ideas in Islamic and socio-intellectual tradition, however, these ideas had unique characters compared to previous tradition; and in many cases, contained some elements related to previous ones. Azra named this intellectual tradition as neo-Sufism.

on. With the enactment of criminal law, The enforcement of Islamic law; civil and criminal, in Banjar was complete. See G.F. Pijper, Beberapa Studi Tentang Sejarah Islam Indonesia 1900-1950 (Jakarta: UI-Press, 1985), p. 73; Yusuf Halidi, Ulama Besar Kalimantan Syekh Mubammad Arsyad al-Banjari (Surabaya: al-Ihsan, 1972), p. 40; Steenbrink, Beberapa Aspek Tentang Islam, p. 95; Zamzam, Syekh Muhammad Arsyad, p. 12; Muhammad Arsyad al-Banjari, Sabil al-Mubtadin (Mesir: Dar al-Fikri, n.d.), p. 22.

${ }^{23}$ Daudi, Maulana Syekh Mubammad Arsyad, pp. 50-51, and pp. 53-54, and pp. 56-57; Aswadie Syukur, "Ulama-Ulama Banjar dan Karyanya," Paper Ilmu-ilmu keislaman di Kalimantan Selatan (Banjarmasin: PPIK IAIN Antasari, 2002), pp. 2-3; Mufrida Zein, Konsepsi Pendidikan Islam Menurut Syekh Mubammad Arsyad al-Banjari, unpublished thesis, (Banjarmasin: Perpustakaan IAIN Antasari, 1994), p. 39. 
Therefore, it should have been understood that al-Banjari's educational paradigm ${ }^{24}$ is neo-Sufism. ${ }^{25}$

Neo-Sufism, from Al-Jabiri's perspective, is an effort to synthesize or make bayāni (naql-textual-dialectic) system close to burbāin ('aqlreasoning-demonstrative) and irfan $\bar{i}$ system (divine inspirationspiritual-metaphysics), ${ }^{26}$ however, these three are not placed in the same position and portion. These depended on its scholars who elaborated the systems. In other word, Neo-Sufism does not have a single variant. It has many. One variant emphasized more on bayan $\bar{i}$ than on burhäin or irfani. In fact, the last two systems are used under bayanì's control. In another variant, ‘irfani had more dominant position than bayan $\bar{i}$ and burbani $\bar{i}$. The other variant paid more attention to bayan $\bar{i}$ and 'irfani and paid a very little attention to burhäí.

In this case, al-Banjari belongs to the first neo-sufism which emphasized more on bayan $\bar{i}$ than on burban $\bar{i}$ and irfani. If it is derived into Islamic education paradigm, it can be said that the paradigm integrated these three systems, however, bayan $\bar{i}$ is more dominant than

\footnotetext{
24 Paradigms, or paradigme in French, was derived from the Greek paradeigma. Para means on the side, beside or in the next to and deigma is an example, the pattern or model. Deigma in the form of the verb means dekynai / show, demonstrate or perform. Therefore, the paradigm, can be interpreted as an example, a pattern or model. Paradigm can also be interpreted as the perspective of looking at things, and arrange it in such a way that it becomes meaningful and understandable. Put simply, a paradigm may mean insight. Lorens Bagus, Dictionary of Philosophy (Jakarta: PT. Scholastic, 2000), p. 779. Glossaries in Ulumul Qur'an, Vol. III, No. 4 (1992), p. 17.

25 According to Fazlur Rahman, Neo-Sufism was an updated version of sufism which is mainly stripped from the character and content of an ecstatic and metaphysical, and replaced with the content from Islamic orthodoxy. Rahman explains further that this new model of Sufism emphasizes and updates the original moral factor and selfcontrol that puritanical in Sufism by developing exaggerated traits from that popular deviated Sufism (unorthodox Sufism). Fazlur Rahman, Islam (Chicago: University of Chicago Press, 1979), pp. 205-206.

${ }^{26}$ Muhammad 'Ābid al-Jābiri, Bunyat al-'Aql al-'Arabi: Dirasab Taḅliliyah Naqdìah li

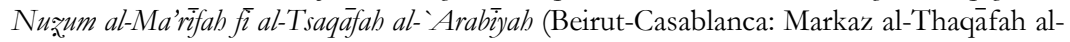
'Arabiyah, 1993), p. 570. Bayan $\bar{i}$ is to obtain coherent truth and knowledge through textual revelation. Burbani is to acquire correspondent truth and knowledge through the thought process that emphasizes the process of reasoning in relation to empirical reality. 'Iffani is to obtain truth and knowledge through the divine inspiration without learning. See Humaidy, "Shaykh Muhammad al-Banjari Arsyad and Islamic Education in South Kalimantan,” Kandil, 3, I (December, 2003), p. 42.
} 
'rfani and burbani $\bar{i}$ repectively. This became more obvious when alBanjari chose to develop fiqh more than other field of studies.

\section{Educational Institution}

Before the era of al-Banjari, educational institution ${ }^{27}$ in Banjar Kingdom was around mosques, community leaders' houses, head of the village's house, teacher's house, the have's house, palace, and the like. For the first few years of his arrival from Haramayn, al-Banjari still used those mentioned institution. However, because more students and more people come to ask for his religious advice and listen to his lecture, the space was not enough. Therefore, bigger educational institution was needed. 28

Al-Banjari started the process of building new Islamic institution by asking Sultan Tahmidullah to give him a land/forest, which was not in used, located around four kilometers from Martapura, to be precise, along Martapura River. This location was spreaded from Riam Kanan and Riam Kiri toward Banjarmasin. ${ }^{29}$ al-Banjari and his son in law, Shaykh Abdul Wahab Bugis, with the help of some students, cleared the forest and then built an Islamic education center.

This education center was self-funded. This was possible because al-Banjari together with some other teachers and students managed to earn money by doing some farming in the location. It did not take a long time to make this center became the most important locus to train the students who were expected to be prominent 'ulama' in South Kalimantan ${ }^{30}$. Before the center was built, al-Banjari built fence around

\footnotetext{
27 Institusi comes from the English word Institutions which means the agency or establishment of an agency and organization. Educational Institution means the process of establishing educational vision and mission in the form of institution or organization. Institutionalization is not solely focused on physical buildings, but also an abstract value that is hidden behind a pattern of leadership and patterns of relationships of people who involved in it. John M. Echols and Hassan Shadily, Dictionary English Indonesia (New York: Scholastic, 1996), p. 325; Pius A. Partanto and M. Dahlan Al-Barry, Ilmiyah Popular Dictionary (New York: Arkola, 1994), p. 262.

28 Humaidy, "Peran Syekh Muhammad Arsyad Al-Banjari dalam Pembaharuan Pendidikan Islam di Kalimantan Selatan Penghujung Abad XVIII," Unpublished Thesis (Yogyakarta: Perpustakaan UIN Sunan Kalijaga, 2003), pp. 117-118.

29 Abu Daudi, Riwayat Hidup Syekh Muhammad Arsyad al-Banjari, unpublished paper (Banjarmasin: Seminar Internasional Pemikiran Syekh Muhammad Arsyad al-Banjari, 2003), pp. 18-19.

${ }^{30}$ Zamzam, Syekh Muhammad Arsyad, p. 89.
} 
the land as the boundaries and soon after that, built a new village which is known as "kampung dalam pagar (village inside fence)" and his educational centre called "punduk dalam pagar". ${ }^{31}$

In designing the concept of inside the fence education (pendidikan dalam pagar), al-Banjari was mostly inspired by some Islamic educational institution in Haramayn without neglecting the influence of Islamic education in Nusantara or to be exact in South Kalimantan. This argument was reasonable since al-Banjari stayed and studied in various Islamic educational institutions in Haramayn for almost a quarter of century and this made him understand deeply about the Islamic educational institution there. Even though al-Banjari was not too much involved, he knew much about madrasah (Islamic school); ribät (riwäk, zawiyah and khanqah). He was involved intensively in the circle of study in Al Harām Mosque, Mecca and An-Nabawi Mosque, Madinah. ${ }^{32}$

31 In Ahmad Basuni's analysis, Dalam Pagar was an Islamic boarding school (pesantren) because there is a place to live for teachers, for teaching, for the students' dormitory. See Ahmad Basuni, Nur Islam in South Kalimantan (Surabaya: Bina Ilmu, 1986), pp. 5254. Being said so, it was not necessarily exactly the same because the term boarding school/ pesantren in South Kalimantan, gained its popularity in the 1970s. The More precise similirity was with surau (a small mosque) in Padang, rangkang, meunasah, dayab in Aceh, punduk in Malay area such as Malaysia, Fatani (Thailand), Jakarta, Palembang (Sumatra) and Brunei Darussalam. South Kalimantan or banjarese is part of Malay society and the Malay culture is very strong. Steenbrink a little disagreed with this statement. He claimed that it is true that Banjar was partly included in malay culture, but, Malay region especially Banjar had the most powerful feature of Java, both in the palace, language and local customs. See Karel A. Steenbrink, Some Aspects of Islam in Indonesia the 19 $9^{\text {th }}$ Century (Jakarta: Bulan Bintang, 1984), p. 94. On the other hand, Faruk HT strongly denied the existence of the strong influence of Java on Banjar because of feudalism which is the heart of Javanese culture, in his opinion, does not influence the culture of Banjar. It was only a thin layer with no significant meaning. Malays remain the dominant element in Banjar culture because it becomes the core of the formation of Banjar society in a long time. This is proved by the language that becomes the language of instruction of Banjar people which nearly $75 \%$ of the vocabulary comes from the Malay language which is expressed in the language in everyday speech, and the language in the arts. Mohammad Najib, (ed.), Demokrasi dalam Perspektif Budaya Nusantara (Yogyakarta: LKPSM NU, 1996), p. 130.

${ }^{32}$ Humaidy, "Peran Syekh Muhammad Arsyad", p. 156. 


\section{Teaching Methods}

Al-Banjari's teaching method ${ }^{33}$ can be categorized into macro and micro method which basically enriched, improved quality and gave new taste to the old educational institution's method.

\section{Macro Method}

1) Contextualization is a method of moving and developing a text or value which is complicated, slow and individual into a more practical, fast and massive one. In teaching context, al-Banjari used a range of Islamic science texts which are written in Arabic, and he modified them into Malay in the form of translation, sharah, compilation, and selection from one text or two or even all texts.

2) Migrationization is a method which obligates the students who are considered finish to migrate or travel to different regions or country.

3) Centralization is a method which centralizes the teaching in one location far from the town and no one had ever applied this before.

4) Integralization is a method which tried to maintain equilibrium between teaching environment at school, home and society.

5) Gradualization is a method of having phases in teaching especially about religious knowledge. This method had been applied by the prophet Muhammad. Al-Banjari implemented this in his teaching in two phases. The first phase is in giving material. al-Banjari taught tawhid knowledge before figh. After those two, the tasawnuf was given.

6) Classification is a method which classifies the students based on some differences. In this case, al-Banjari put his students in groups based on sex, talent and intelligence.

\section{Micro Method}

1) Uswah Hasanah is a method in which teachers are the role models for students. The teachers' self building as role models can be

\footnotetext{
${ }^{33}$ Method in English was from Latin language methodus and Greek methodos. Meta means after, and on top and hodos means a road or a way. Bagus, Dictionary, p. 586. The method can be interpreted as ways or steps that are used in conveying the ideas, thoughts or insights that are systematically arranged and planned based on the theory, certain concepts and principles contained in various related disciplines. See Abuddin Nata, Islamic Perspectives on Learning Strategy (Jakarta: Kencana, 2009), p. 176.
} 
accomplished by improving religious knowledge, devotion, service, dedication and moral integrity.

2) Halaqah is a method in which teacher (read: tuan guru) reads a book aloud surrounded by his students who pay good attention, listen to him, and take a note of difficult vocabulary of Arabic words. ${ }^{34}$

3) Sorogan is a method in which students, in turn, meet the teacher and bring the book that they are going to learn. This method, nowadays, is called tutorship or mentorship. ${ }^{35}$

4) Lecturing is a one way communication method in delivering message and information (teaching material) from teachers to students.

5) Question-Answer (Q-A) is a method in which teacher ask questions to students about the previous material. From his writings, it seems that al-Banjari likes to use Q-A since it can be found almost in every chapter of his books for example in Sabil al-Mubtadin, Luqtat al-Ajlän and Tubfat al-Räghibin.

6) Discussion is a method in which interaction and communication occur between teachers and students to solve problems or to take a conclusion.

7) Giving assignment is a teaching method in which teacher gives assignment to the students in the form of material or skills to be accomplished in certain duration of time.

8) Drill is a teaching method for a subject in which practice is more dominant than theory

9) Takhassus is a special method in which teachers intensively control, advise, and guide students to do suluk, khalwah or other spiritual practice.

All methods; macro or micro, can be applied one by one or combined in the same time. In sort, these methods enrich, develop, improve and give new meaningful values to the previous educational institution.

\footnotetext{
34 Muhrin Baderi, "Profil Pesantren di Kalimantan Selatan," paper Profil Pendidikan Islam di Kalimantan Selatan (Banjarmasin: 11-12 Nopember 1986), p. 6.

${ }^{35}$ Ibid.
} 


\section{Teaching Materials}

Before al-Banjari's arrival, the subjects ${ }^{36}$ of religious teaching were very simple. In teaching the Qur'an, the focus was only on reciting, memorizing and reciting with rhyme. In figh, it focused on rules of performing prayers, ablution, and pray. Sufism was the only subject that was taught in depth till wihdat al-wnjüd phase. Nevertheless, the understanding level of this phase was doubtfull since it was not supported by the deep understanding of tawhid and fiqh as part of important phases which should be gone through by the faithfull people. ${ }^{37}$

In al-Banjari's era, the religious subjects was learnt in depth and in wider scope. Besides teaching reciting, memorizing, and reciting the Qur'an with rhyme, it was accompanied by understanding Arabic language, Tafsir, Tajwid as well as Khatt and Calligraphy. Al-Banjari was best at calligraphy and we can still enjoy the beauty of his work today.

In Figh subject, the materials had been arranged systematically from Thaharah to Haij with additional local cases such as islamic rules on eating bee and snail. In tawhid, the material had covered various theology mainstream in Islam, concept of faith and the opposite concept such as unbeliever, polytheist/musyrik, backslide/murtad, zindiq, heresy, superfluous, and other mis-leading faiths. In teaching tasawnuf, he prefered tasawmuf which was acceptable by shari'ah and not the opposite one. He also taught falaq subject, farming and building irrigation. 38

In teaching, al-Banjari did not only use his own writing as the textbooks but also textbooks written by other Islamic scholars. Textbooks used in Malay area was usually written in Malay, yet, alBanjari also used the textbooks which were written in Arabic especially those written by scholars from Shäfi'i school in fiqh and Ahlussunah school in tawhid and tasawwuf. ${ }^{39}$

\footnotetext{
36 matter from Latin language materia which means material. Bagus, Dictionary, p. 587.

${ }^{37}$ See Humaidy, "Syekh Muhammad Arsyad", p. 48.

38 Ibid., p. 49.

${ }^{39}$ Ibid.
} 


\section{Conclusion}

Al-Banjari's thought on education covered educational paradigm, educational institution, teaching methods, and teaching materials/ subjects. Al-Banjari's educational paradigm was neo-sufism which emphasized more on bayan $\bar{i}$ than $\operatorname{irf} \bar{a} \bar{i} \bar{i}$ and burbani $\overline{\text {. This }}$ was obvious when al-Banjari chose to develop figh more than other fields of studies.

Al-Banjari's eduational institution was kind of new in South Kalimantan since this introduced the society with the first semi formal educational institution where the religious service could be concentrated in one place and religious studies could be taught in depth.

Al-Banjari's teaching method can be categorized into two; macro (contextualization, migrationization centralization, integralization, gradualization, integralization and classification) and micro (uswah hasanah, halaqah, sorogan, lecturing, QA, discussion, assignment, drill, and takhassus). These methods basically enrich, develop, improve and give new meaningful values to the previous educational institutions.

Before al-Banjari's arrival, the subjects of religious teaching were very simple. In al-Banjari's era, the religious subjects was learnt in depth and in wider scope. Furthermore, in teaching, al-Banjari did not only use his own writing as the textbooks but also textbooks written by other Islamic scholars. []

\section{Bibliography}

\section{Books and Articles}

'Abid, Muhammad al-Jābirí. Bunyat al-'Aql al-'Arabì: Dirāsab Taḥlitiyah Naqdiyah li Nurum al-Ma'rifah fì al-Tsaqäfah al-'Arabijah. BeirutCasablanca: Markaz al-Thaqāfah al-`Arabiyah, 1993.

al-Banjari, Muhammad Arsyad. Sabīl al-Mubtadin. Mesir: Dar al-Fikri, n.d.

Anonim. Silsilab Tuan Guru Haji Zaini Gani. Surabaya: n.p., n.d.

Azra, Azyumardi. Jaringan Ulama. Bandung, Mizan, 1994.

Baderi, Muhrin. "Profil Pesantren di Kalimantan Selatan." paper on seminar Profil Pendidikan Islam di Kalimantan Selatan. Banjarmasin: 11-12 Nopember 1986.

Bagus, Lorens. Kamus Filsafat. Jakarta, PT. Gramedia, 2000. 
Basuni, Ahmad. Jiwa yang Besar Shaykh Muhammad Arsyad al-Banjari. Bandung: Pustaka Galunggung, 1971.

--------. Nur Islam di Kalimantan Selatan. Surabaya: Bina Ilmu, 1986.

van Bruinessen, Martin. Kitab Kuning. Bandung: Mizan, 1995.

Daudi, Abu. Riwayat Hidup Shaykh Muhammad Arsyad al-Banjari. Unpublished paper. Banjarmasin: Seminar Internasional Pemikiran Shaykh Muhammad Arsyad al-Banjari, 2003.

--------. Maulana Shaykh Muhammad Arsyad al-Banjari. Martapura: Sullam al-Ulum, 1996.

Echols, John M., and Hassan Shadily. Kamus Inggris Indonesia. Jakarta: Gramedia, 1996.

Hafiz, A. Ansary HZ. "Peranan Shaykh Muhammad Arsyad al-Banjari di dalam Pengembangan Islam di Kalimantan Selatan." Khazanah. Vol. I, No.1, February 2002.

Halidi, Yusuf. Ulama Besar Kalimantan Shaykh Mubammad Arsyad alBanjari. Surabaya: al-Ihsan, 1972.

Hamka. Sejarah Umat Islam IV . Jakarta: Bulan Bintang, 1976.

Humaidy, "Shaykh Muhammad Arsyad al-Banjari dan Pendidikan Islam di Kalimantan Selatan.” Kandil, 3, I (December, 2003).

-------. Peran Shaykh Muhammad Arsyad Al-Banjari dalam Pembaharuan Pendidikan Islam di Kalimantan Selatan Penghujung Abad XVIII. unpublished thesis. Yogyakarta: Perpustakaan UIN Sunan Kalijaga, 2003.

Kadir, M.S. "Shaykh Muhammad Arsyad al-Banjari Pelopor Dakwah Islam di Kalimantan Selatan.” Mimbar Ulama No. 6, 1976.

Najib, Mohammad (ed.). Demokrasi dalam Perspektif Budaya Nusantara. Yogyakarta: LKPSM NU, 1996.

Nata, Abuddin. Perspektif Islam tentang Strategi Pembelajaran. Jakarta: Kencana, 2009.

Partanto, Pius A., and M. Dahlan Al-Barry. Kamus Ilmiyah Populer. Surabaya: Arkola, 1994.

Pijper, G.F. Beberapa Studi Tentang Sejarah Islam Indonesia 1900-1950. Jakarta: UI-Press, 1985.

Rahman, Fazlur. Islam. Chicago: University of Chicago Press, 1979. 
Shagir, HW. Muhd. Abdullah Shaykh Mubammad Arsyad al-Banjari, Pengarang Sabil al-Mubtadin. Kuala Lumpur: Khazanah Fataniyah, 1990.

- Shaykh Muhammad Arsyad al-Banjari Matahari Islam. Kuala Mempawah: Yayasan Pendidikan dan Dakwah Islamiyah alFathanah, 1983.

Shaykh Muhammad Arsyad al-Banjari, Matahari Islam, Pontianak: Yayasan Pendidikan \& Dakwah al-Fatanah, 1983.

Sidik, M. Luthfi. Salasilah Siti Fathimah, Sebutir Telur. Salatiga: n.p., 1992.

Steenbrink, Karel A. Beberapa Aspek Tentang Islam di Indonesia Abad ke19. Jakarta: Bulan Bintang, 1984.

Syukur, Aswadie. "Ulama-Ulama Banjar dan Karyanya." Unpublished paper Ilmu-Ilmu Keislaman di Kalimantan Selatan. Banjarmasin: PPIK IAIN Antasari, 2002.

Zamzam, Zafri. Shaykh Muhammad Arsyad al-Banjari: Ulama Besar Juru Dakwah. Banjarmasin: Karya, 1979.

Zein, Mufrida. Konsepsi Pendidikan Islam Menurut Shaykh Muhammad Arsyad al-Banjari. Unpublished paper. Banjarmasin: Perpustakaan IAIN Antasari, 1994.

Zuhri, Saifuddin. Sejarah Kebangkitan Islam dan Perkembangannya di Indonesia. Bandung: PT. al-Ma’arif, 1981. 